\title{
PERAN KEPALA SEKOLAH SEBAGAI ADMINISTRATOR DAN SUPERVISOR
}

\author{
Hamidi $^{1}$, Nuzuwar ${ }^{2}$, Ifnaldi Nurmal ${ }^{3}$ \\ Program Pascasarjana IAIN Curup ${ }^{1,2,3}$ \\ hamidi2019@gmail.com ${ }^{1}$
}

\begin{abstract}
ABSTRAK
Tujuan dari penelitian ini adalah untuk mengetahui bagaimana peran kepala sekolah sebagai administrator dan supervisor. Rancangan penelitian ini menggunakan pendekatan deskriftif kualitatif. Subyek penelitian terdiri dari kepala sekolah, guru dan staf pegawai di SMP Negeri Megang Sakti Kabupaten Musi Rawas. Hasil penelitian menjelaskan bahwa kepala sekolah sudah menerapkan tugas pokok dan fungsinya sebagai kepala sekolah. Simpulan, dari penelitian ini adalah Kepala sekolah SMP Negeri Megang Sakti telah membuat program kerja yang baik, hal ini dapat dilihat dari kegiatan sekolah, baik yang berhubungan dengan siswa maupun dengan tenaga pendidik dan kependidikan sekolah.
\end{abstract}

Kata Kunci: Program Kerja, Peran Kepala Sekolah

\section{ABSTRACT}

The purpose of this study was to find out how the role of the principal as an administrator and supervisor. The design of this study uses a qualitative descriptive approach. The research subjects consisted of principals, teachers and staff staff at Megang Sakti Public Middle School, Musi Rawas District. The results of the study explained that the principal had applied his main tasks and functions as the principal. The conclusions of this study are that the Principal of Megang Sakti Middle School has made a good work program, this can be seen from school activities, both related to students and with educators and school education.

Keywords: Work Program, Role of Principal

\section{PENDAHULUAN}

Kinerja guru tidak terlepas dari pengawasan kepala sekolah sebagai administrator dan supervisor, kepala sekolah sebagai manejer yang mengatur perkembangan sekolah baik dari segi perencanaan, pengawasan dan evaluasi. Menurut Purwanto (2004) kepala sebagai administrator adalah membuat perencanaan, menyusun organisasi sekolah, koordinator dan pengarah dan melaksanakan pengelolaan kepegawaian. Salah satu fungsi utama dan pertama yang menjadi tanggung jawab kepala sekolah adalah membuat atau menyusun perencanaan.

Organisasi merupakan fungsi administrasi dan manajemen yang penting pula disamping perencanaan, disamping sebagai alat, organisasi dapat pula 
dipandang sebagai wadah atau struktur dan sebagai proses, sebagai wadah organisasi merupakan tempat kegiatan-kegiatan administrasi itu dilaksanakan, jika dipandang sebagai proses, maka organisasi merupakan kegiatan-kegiatan atau menyusun dan menetapkan hubungan-hubungan kerja antar personal. Kewajibankewajiban, wewenang dan tanggung jawab masing-masing bagian atau personal yang termasuk dalam organisasi itu disusun dan ditetapkan menjadi pola-pola kegiatan yang tertuju kepada tercapainya tujuan-tujuan yang telah ditetapkan. Kepala sekolah sebagai administrator pendidikan perlu menyusun organisasi sekolah yang dipimpinya dan melaksanakan pembagian tugas serta wewenangnya kepada guru-guru dan pegawai sekolah sesuai dengan struktur organisasi sekolah yang telah disusun dan disepakati bersama.

Adanya bermacam-macam tugas dan pekerjaan yang dilakukan oleh banyak orang, memerlukan adanya koordinasi serta pengarahan dari pimpinan sekolah. Adanya koordinasi serta pengarahan yang baik dan berkelanjutan dapat menghindarkan kemungkinan terjadinya persaingan yang tidak sehat antarbagian atau antarpersonal sekolah dan kesimpangsiuran dalam tindakan, dengan kata lain adanya pengorganisasian yang baik memungkinkan semua bagian atau personal bekerja sama saling membantu kearah satu tujuan yang telah ditetapkan seperti kerjasama saling membantu kearah satu tujuan yang telah ditetapkan seperti kerjasama antara urusan kurikulum dan pengajaran dengan guru-guru, kerjasama antara bagian tata usaha dengan wali kelas dan guru-guru, kerjasama antara POMG atau BP3 dengan urusan bimbingan dan konseling dan para wali kelas.

Pengelolaan kepegawaian mencakup di dalamnya penerimaan dan penempatan guru dan pegawai sekolah, pembagian kerja tugas guru dan pegawai sekolah, usaha kesejahteraan guru dan pegawai sekolah, mutasi atau promosi guru dan pegawai sekolah. Tugas-tugas yang menyangkut pengelolaan kepegawaian ini sebagian besar dikerjakan oleh bagian tata usaha sekolah seperti pengusulan guru dan pegawai baru, kenaikan pangkat guru dan pegawai sekolah.

Menurut Schermerchon dalam Wahjosumidjo (2002) dalam lingkungan organisasi kepemimpinan terjadi melalui dua bentuk yaitu kepemimpinan formal dan informal. Kepemimpinan formal terjadi apabila dilingkungan organisasi jabatan otoritas formal dalam organisasi tersebut diisi oleh orang-orang yang ditunjuk atau dipilih melalui proses seleksi, sedangkan kepemimpinan informal terjadi, dimana kedudukan pemimpin dalam suatu organisasi diisi oleh orangorang yang muncul dan berpengaruh terhadap orang lain karena kecakapan khusus atau berbagai sumber yang dimilikinya dirasakan mampu memecahkan persoalan organisasi serta memenuhi kebutuhan dari anggota organisasi yang bersangkutan.

Berdasarkan kondisi dilapangan di SMP Negeri Megang Sakti Kabupaten Musi Rawas peran kepala sekolah sebagai administrator dan supervisor masih pada tahapan kepemimpinan formal, artinya sebatas tugas semata, kurang mengidentifikasi karekteristik tenaga pendidik, sehingga iklim organisasi kurang 
kondusif, kurang merencanakan tenaga kependidikan sekolah, merekrut, mengembangkan tenaga professional guru, memelihara dan menilai. Kepala sekolah sebagai administrator dan supervisor hanya sebatas formalitas, tetapi seni memimpin dan menyusun administrasi sekolah belum maksimal dilakukan dan diwujudkan, tanpa hal itu rasanya sulit suatu lembaga untuk mewujudkan visi dan misi sekolah secara efektif dan efisien.

\section{METODE PENELITIAN}

\section{Rancangan Penelitian}

Rancangan penelitian ini menggunakan pendekatan deskriftif kualitatif, artinya semua data yang ditemukan dilapangan penelitian dideskripsikan dalam bentuk bahasa dan kalimat, dimana peneliti adalah sebagai instrumen kunci, pengambilan sampel, sumber data dilakukan secara purposive dan snowwball, teknik pengumpulan dengan triangulasi (gabungan).

\section{Sampel Penelitian}

Sampel penelitian dalam penelitian segenap orang yang dipandang oleh peneliti dapat memberikan data tentang peran kepala sekolah sebagai administrator dan supervisor di SMP Negeri Megang Sakti Kabupaten Musi Rawas. Subyek penelitian terdiri dari kepala sekolah, guru dan staf pegawai di SMP Negeri Megang Sakti Kabupaten Musi Rawas

\section{Teknik Pengumpulan dan Pengembangan Instrumen Penelitian Teknik Pengumpulan Data}

Pada penelitian ini menggunakan dua cara yaitu, wawancara dan dokumentasi. Teknik dokumentasi hanya digunakan sebagai pelengkap data. Data yang diambil dalam penelitian ini berupa data yang berhubungan dengan peran kepala sekolah sebagai administrator dan supervisor di SMP Negeri Megang Sakti Kabupaten Musi Rawas.

\section{Observasi}

Teknik ini dapat memberikan gambaran nyata terutama perilaku nonverbal yang tentunya merupakan fokus penelitian. Jenis observasi yang digunakan dalam penelitian ini ada dua teknik observasi yaitu: 1) observasi tidak berpartisipasi dan 2) obsevasi berpartisipasi atau pengamatan terlibat (partisipan observasi). Observasi tidak berpartisipasi digunakan peneliti untuk mengumpulkan data tentang peran kepala sekolah sebagai administrator dan supervisor di SMP Negeri Megang Sakti Kabupaten Musi Rawas.

Observasi dilakukan untuk mendapatkan data dan informasi yang diperlukan dan dikumpulkan melalui pengamatan langsung di SMP Negeri Megang Sakti Kabupaten Musi Rawas baik secara terbuka maupu secara tertutup. Hasil dari pengamatan langsung dibuat catatan lapangan yang harus disusun 
setelah mengadakan hubungan langsung dengan subyek yang diteliti. Catatan yang diperoleh masih merupakan data dari observasi, maka suatu keharusan bagi peneliti untuk membuat catatan yang lebih komprehensif, dalam melakukan pengamatan ini peneliti sendiri yang melakukannya.

\section{Wawancara}

Substansi materi wawancara dan responden. Substansi materi dalam wawancara adalah mengenai peran kepala sekolah sebagai administrator dan supervisor hal ini menyangkut antara lain: Pengalaman dan pembuatan responden apa yang telah dikerjakan dan lazim dikerjakan dalam menjelaskan peran kepala sekolah sebagai administrator dan supervisor. Pendapat, pandangan, tanggapan, laporan atau pikirannya tentang peran kepala sekolah sebagai administrator dan supervisor di.Pengatahuan, fakta-fakta apa yang diketahui tentang peran kepala sekolah sebagai administrator dan supervisor.Penginderaan apa yang dilihat, didengar, dirasakan, dikecap dalam menjelaskan peran kepala sekolah sebagai administrator dan supervisor.Latar belakang pendidikan, pekerjaan, daerah asal, tempat tinggal, lama berkecimpung di dunia pendidikan dalam menjelaskan peran kepala sekolah sebagai administrator dan supervisor.

\section{Dokumentasi}

Pengumpulan data melalui dokumentasi adalah data yang baik langsung maupun tidak langsung berhubungan dengan peran kepala sekolah sebagai administrator dan supervisor di SMP Negeri Megang Sakti Kabupaten Musi Rawas. Dokumentasi yang dilaksanakan dalam penelitian ini adalah dokumentasi suatu peristiwa atau kejadian malalui foto.

\section{Instrumen Penelitian}

Peneliti sebagai instrumen dalam praktiknya menggunakan berbagai teknik pengumpulan data. Ada beberapa keuntungan menjadikan peneliti sebagai instrumen penelitian ini, antara lain yaitu a) peneliti sebagai instrumen dapat berinteraksi dengan lingkungan dan responden yang ada, memiliki kepekaan dan dapat beraksi terhadap stimulus yang diperkirakan bermakna bagi penelitian, b) peneliti sebagai instrument dapat menyesuaikan diri terhadap semua aspek keadaan dan dapat memahami situasi dengan segenap dinamikanya, peneliti dapat mengumpulkan data aneka ragam data pada berbagai jenis dan tingkatan, karena sifat holistik penelitian menuntut kemampuan menangkap fenomena dengan segenap konteksnya secara simultan, c) peneliti sebagai simultan dapat merasakan, memahami dan menghayati secara kompeten dan simultan atas aneka stimulus yang muncul secara kontekstual atau melalui proses interaksi dan merumuskan kesimpulan yang sementara yang sangat berguna untuk menentukan arah penggalian data selanjutnya guna memperdalam dan atau mempertajam temuan penelitian, d) dengan peneliti sebagai instrumen penelitian memungkinkan 
kalau ada fenomena atau ada responden yang memiliki pendapat menyimpang, bahkan bertentangan dapat digali lebih jauh dan mendalam untuk mengetahui mengapa yang bersangkutan berpendapat seperti itu. Keragaman responden ini justru dapat dipakai untuk mempertinggi pemahaman dan vitalitas dapat mengenal aspek-aspek yang diteliti, e) peneliti sebagai instrumen dapat segera menganalisis data yang diperoleh sehingga tidak bisa dan pada saat itu pula dapat segera mengumpulkan data lebih lanjut sebagai umpan balik untuk memperoleh penegasan, perubahan, perbaikan dan penolokan terhadap fenomena yang diperoleh dan sumber data atau informan penelitian.

Peneliti selama berlangsung pengumpulan data berperan sebagai instrumen yang dibantu oleh perangkat mekanik berupa perekam suara (cassette recorder) yang berukuran kecil dalam penggunaan alat tersebut dilakukan secara hati-hati sehingga diharapkan proses pengumpulan data yang sedang dilakukan tidak akan terganggu oleh perangkat mekanik tersebut.

\section{Teknik Analisis Data}

Untuk menyajikan agar data lebih bermakna dan mudah dipahami. Maka langkah analisis data yang dilakukan adalah: pengumpulan data, reduksi data, penyajian data dan penarikan kesimpulan. Reduksi data bisa diartikan sebagai proses pemilihan, pemutusan perhatian pada penyederhanaan, pengabsahan dan transformasi data kasar yang muncul dari permasalahan yang ada di lapangan dan sudah direkam dengan baik oleh peneliti. Penyajian data adalah memaparkan data dalam bentuk sekumpulan informasi yang berupa teks naratif, jaringan, matriks dan lain-lain. Dengan cara penyajian tersebut memberikan kemungkinan bagi peneliti untuk memahami makna dari masing-masing data serta menarik kesimpulan dan melengkapi data-data yang masih kurang melalui pengumpulan data tambahan dan reduksi data. Kesimpulannya bahwa data yang terkumpul perlu diverifikasi terus-menerus selama penelitian berlangsung agar data yang diperoleh dapat dijamin keabsahannya dan keobyektifannya. Data kinerja yang diperoleh dengan dokumentasi dan wawancara dianalisis dengan analisis deskriftif.

Tahap selanjutnya adalah auditing. Pelaksanaan auditing dilakukan dengan merujuk pada pendapat Harper yang dikutip oleh Moleong, yaitu 1) pre-entri, 2) penetapan yang dapat diaudit, 3) persetujuan auditor dan auditi, 4) penetapan keabsahan dan 5) penutup auditing. Dimaksud dengan auditor dalam penelitian ini dosen pembimbing, merupakan orang yang memiliki kemampuan untuk mengaudit. Pada waktu melakukan auditing, peneliti menjelaskan kepada auditor tentang tujuan, manfaat, proses dan hasil temuan selama peneliti mengadakan wawancara, dan analisis dokumen. 


\section{HASIL DAN PEMBAHASAN}

\section{Program kepala sekolah sebagai administrator dan supervisor}

Kepala sekolah SMP Negeri Megang Sakti telah membuat program kerja yang baik, hal ini dapat dilihat dari kegiatan sekolah baik yang berhubungan dengan siswa maupun dengan tenaga pendidik dan kependidikan sekolah. Kepala sekolah merencanakan program sekolah berdasarkan visi dan misi sekolah, sehingga perencanaan program sekolah relevan dengan kebutuhan warga sekolah. Dalam merencanakan kegiatan sekolah kepala sekolah terlebih dahulu mengidentifikasi kebutuhan warga sekolah sehingga program yang akan dibuat benar-benar bermanfaat bagi peningkatan kualitas sekolah.

Perencanaan merupakan langkah awal dalam pengelolaan program sekolah. Dengan perencanaan yang matang, seluruh kegiatan dapat berjalan dengan baik dan sesuai dengan apa yang telah direncanakan. Perencanaan tidak lain merupakan kegiatan untuk menetapkan tujuan yang akan dicapai beserta cara-cara untuk mencapai tujuan tersebut. Sebagaimana disampaikan oleh Boone dan Kurtz (1984) bahwa: planning may be defined as the proses by which manager set objective, asses the future, and develop course of action designed to accomplish these objective. Sedangkan Handoko (1995) mengemukakan bahwa pencanaan (planning) adalah pemilihan atau penetapan tujuan organisasi dan penentuan strategi, kebijaksanaan, proyek, program, prosedur, metode, sistem, anggaran dan standar yang dibutuhkan untuk mencapai tujuan. Pembuatan keputusan banyak terlibat dalam fungsi ini."

Arti penting perencanaan terutama adalah memberikan kejelasan arah bagi setiap kegiatan, sehingga setiap kegiatan dapat diusahakan dan dilaksanakan seefisien dan seefektif mungkin. Handoko (1995) mengemukakan sembilan manfaat perencanaan bahwa perencanaan: (a) membantu manajemen untuk menyesuaikan diri dengan perubahan-perubahan lingkungan; (b) membantu dalam kristalisasi persesuaian pada masalah-masalah utama; (c) memungkinkan manajer memahami keseluruhan gambaran; (d) membantu penempatan tanggung jawab lebih tepat; (e) memberikan cara pemberian perintah untuk beroperasi; (f) memudahkan dalam melakukan koordinasi di antara berbagai bagian organisasi; (g) membuat tujuan lebih khusus, terperinci dan lebih mudah dipahami; (h) meminimumkan pekerjaan yang tidak pasti; dan (i) menghemat waktu, usaha dan dana.

\section{Peran kepala sekolah sebagai administrator dan supervisor dalam menyusun organisasi sekolah}

Kepala sekolah SMP Negeri Megang Sakti telah melakukan perannya dengan baik dalam menyusun organisasi sekolah, hal ini dapat dilihat dari pembagian tugas kerja dan delegasi kewenangan kepada wakil kepala sekolah yang sesuai dengan bidang dan kemampuannya masing-masing, sehingga beban kerja telah dibagikan sesuai dengan kemampuan dan pengalaman masing-masing 
dan dengan demikian tugas pokok dan fungsi masing-masing telah dibebankan dan dipertanggunjawabkan oleh bawahan dalam menjalankan tugas pokok dan fungsinya.

Kegiatan pengorganisasian adalah sangat penting dalam pembagian bobot kerja untuk pelaksanaan tugas bawahan. Terry (1986) mengemukakan bahwa pengorganisasian adalah tindakan mengusahakan hubungan-hubungan kelakuan yang efektif antara orang-orang, sehingga mereka dapat bekerja sama secara efisien, dan memperoleh kepuasan pribadi dalam melaksanakan tugas-tugas tertentu, dalam kondisi lingkungan tertentu guna mencapai tujuan atau sasaran tertentu.

Berkenaan dengan pengorganisasian ini, Nawawi (1992) mengemukakan beberapa asas dalam organisasi, diantaranya adalah : (a) organisasi harus profesional, yaitu dengan pembagian satuan kerja yang sesuai dengan kebutuhan; (b) pengelompokan satuan kerja harus menggambarkan pembagian kerja; (c) organisasi harus mengatur pelimpahan wewenang dan tanggung jawab; (d) organisasi harus mencerminkan rentangan kontrol; (e) organisasi harus mengandung kesatuan perintah; dan (f) organisasi harus fleksibel dan seimbang.

\section{Peran kepala sekolah sebagai administrator dan supervisor dalam mengkoordinasi dan mengarahkan bawahan}

Kepala sekolah SMP Negeri Megang Sakti Kabupaten Musi Rawas telah mengarahkan dan mengkoordinasi bawahan dengan baik hal ini dapat dilihat dari pembinaan dan arahan kepala sekolah kepada guru dalam peningkatan prestasi belajar siswa dan juga kepada staf administrasi sekolah agar mengelola kegiatan administrasi sekolah dengan baik. Kegiatan koordinasi dan arahan kepala sekolah merupakan kegiatan yang sangat penting sekali dalam pelaksanaan kegiatan program sekolah, apabila terjadi kendala kepala sekolah melakukan kegiatan arahan dan bimbingan kepada bawahan sehingga bawahan dapat bekerja secara lebih baik lagi.

\section{Peran kepala sekolah sebagai administrator dan supervisor dalam mengelola tenaga pendidik dan kependidikan}

Kepala sekolah SMP Negeri Megang Sakti telah menjalankan tugasnya sebagai kepala sekolah dalam pengelolaan tenaga pendidik dan kependidikan, hal ini dapat dilihat dari pretasi yang telah dicapai para tenaga pendidik baik secara nasional, provinsi dan kabupaten terutama dalam penulisan karya ilmiah dan penelitian tindakan kelas, dengan pengelolaan tenaga pendidikan yang baik akan menjadi aset yang paling berharga bagi sekolah dalam meningkatkan kualitasnya 


\section{Peran kepala sekolah sebagai administrator dan supervisor dalam melakukan kepengawasan}

Kepala sekolah SMP Negeri Megang Sakti Kabupaten Musi Rawas telah melakukan fungsiya sebagai pegawas dan supervisor hal ini dapat terlihat dari rutinitas dan aktivitas kepala sekolah dalam mengontrol kegiatan pelaksanaan kegiatan belajar dan mengajar di sekolah. Kepala sekolah melakukan kegiatan kepangawasan agar dalam pelaksanaan kegiatan dapat diketahui oleh kepala sekolah mengenai kendala dan hambata, sehingga dapat dengan cepat dicarikan solusi dan permaslahannya.

\section{Peran kepala sekolah sebagai administrator dan supervisor dalam} melakukan kegiatan monitoring dan evaluasi

Kepala sekolah telah melakukan fungsinya manajemen terakhir yakni kegiatan monitoring dan evaluasi dengan kegiatan ini kepala sekolah dapat dengan jelas mengetahui kekurangan dan kelemahan sekolah sehingga dengan adanya kegiatan monitoring dan evaluasi dapat dijadikan perbaikan kedepannya.

Pengawasan (controlling) merupakan fungsi manajemen yang tidak kalah pentingnya dalam suatu organisasi. Semua fungsi terdahulu, tidak akan efektif tanpa disertai fungsi pengawasan. Sementara itu, Robert J. Mocker sebagaimana disampaikan oleh Handoko (1995) mengemukakan definisi pengawasan yang di dalamnya memuat unsur esensial proses pengawasan, bahwa pengawasan manajemen adalah suatu usaha sistematik untuk menetapkan standar pelaksanaan dengan tujuan - tujuan perencanaan, merancang sistem informasi umpan balik, membandingkan kegiatan nyata dengan standar yang telah ditetapkan sebelumnya, menentukan dan mengukur penyimpangan-penyimpangan, serta mengambil tindakan koreksi yang diperlukan untuk menjamin bahwa semua sumber daya perusahaan dipergunakan dengan cara paling efektif dan efisien dalam pencapaian tujuan-tujuan perusahaan.

Dengan demikian, pengawasan merupakan suatu kegiatan yang berusaha untuk mengendalikan agar pelaksanaan dapat berjalan sesuai dengan rencana dan memastikan apakah tujuan organisasi tercapai. Apabila terjadi penyimpangan di mana letak penyimpangan itu dan bagaimana pula tindakan yang diperlukan untuk mengatasinya. Selanjutnya dikemukakan pula oleh Handoko (1995) bahwa proses pengawasan memiliki lima tahapan, yaitu : (a) penetapan standar pelaksanaan; (b) penentuan pengukuran pelaksanaan kegiatan; (c) pengukuran pelaksanaan kegiatan nyata; (d) pembandingan pelaksanaan kegiatan dengan standar dan penganalisaan penyimpangan-penyimpangan; dan (e) pengambilan tindakan koreksi, bila diperlukan.

Fungsi-fungsi manajemen ini berjalan saling berinteraksi dan saling kait mengkait antara satu dengan lainnya, sehingga menghasilkan apa yang disebut dengan proses manajemen. Dengan demikian, proses manajemen sebenarnya merupakan proses interaksi antara berbagai fungsi manajemen. Dalam perspektif 
persekolahan, agar tujuan pendidikan di sekolah dapat tercapai secara efektif dan efisien, maka proses manajemen pendidikan memiliki peranan yang amat vital. Karena bagaimana pun sekolah merupakan suatu sistem yang di dalamnya melibatkan berbagai komponen dan sejumlah kegiatan yang perlu dikelola secara baik dan tertib.

\section{SIMPULAN}

Simpulan penelitian ini secara umum tentang peran kepala sekolah sebagai administrator dan supervisor di SMP Negeri Megang Sakti Kabupaten Musi Rawas adalah kepala sekolah telah menerapkan tugas pokok dan fungsinya sebagai kepala sekolah hal ini dapat dilihat dari program yang telah direcanakan dan dilaksanakan kepala sekolah yang sesuai dengan visi dan misi sekolah, kemudian kepala sekolah dapat menyusun kegiatan organisasi sekolah dengan baik hal ini dapat dilihat dari pembagian tugas kerja yang sesuai dengan kemampuan bawahan, kepala sekolah juga mampu mengarahkan dan mengkoordiansi bawahan dalam menjalankan tugas pokok dan fungsinya, dan terakhir kepala sekolah berhasil melakukan kegiatan monitoring dan evaluasi sehingga kegiatan sekolah berjalan sesuai denganapa yang diharapkan.

\section{DAFTAR PUSTAKA}

Arikunto, S. (2002). Dasar-Dasar Evaluasi Pendidikan. Jakarta: Bumi Aksara

Handoko, H. (1995). Manajemen Pendidikan. Jakarta: Balai Pustaka

Kurtz, K. (1984). Manajemen Pendidikan. Bandung: Graha Ilmu

Nawawi, N. (1992). Manajemen Pendidikan. Bandung: Alphabeta

Purwanto, N. (2004). Administrasi dan Supervisi Pendidikan. Bandung: PT Remaja Rosdakarya 